\title{
Notes, references and select discography
}

The select discography for each Chapter is not meant to be comprehensive of artists or musical styles. It merely serves as a supplementary playlist, or soundtrack - an indication of what the book should sound like. The best way to read it is with the accompaniment of two albums produced by Adrian Sherwood: one which takes its name from this book, Gary Clail On-U Sound Sound System End of the Century Party; and the other the best 'football' record ever made, Barmy Army: The English Disease.

\section{A'post'-script}

\section{From my generation to regeneration: a 'post'-script}

1 'Drinking and Disorder: A Study of Non-Metropolitan Violence', Home Office Research Study 108, 1989.

2 See A. Kroker and M. Kroker: Body Invaders: Sexuality and the Postmodern Condition (Macmillan, London, 1988), A. Kroker and D. Cook: The Postmodern Scene: Excremental Culture and Hyperaesthetics (Macmillan, London, 1988) and A. Kroker, M. Kroker and D. Cook: Panic Encyclopaedia (Macmillan, London, 1989). See also S. Lotringer: Overexposed (Pantheon, New York, 1988).

For a tongue-in-chic antidote to the media excess, play My Life With The Thrill Kill Cult: 'Nervous Xians/The Devil Does Drugs' (Wax 


\section{The end-of-the-century party}

Trax); for News at Ten theme and more, Renegade Sound Wave: 'The Kray Twins' (Rhythm King); Front 242: Official Version (RRE) is a good example of the sound of what has been dubbed 'New Beat' - in existence since the early 1980s despite the media label being applied only in the late 1980s; for a good sampler including Front 242 and Canadian outfit Skinny Puppy, see Various Artists: This is Electronic Body Music (Ediesta); a useful introduction to various styles of contemporary dance (hip-hop, house, garage) is found on Various Artists: Upfront 9 (Serious), and Soul II Soul: Club Classics Vol 1 (10); see also A Guy Called Gerald: 'Voodoo Ray' (Rham) and Hot Lemonade (Rham), and 808 State: Newbuild and Quadrastate (Creed); for the (post)modern sound of Detroit, see Various Artists: Techno(10); and for the North of England, see Various Artists: Freak Beats Vol 1: A Tacky Souvenir of Pre-revolutionary Northern England (Scam/Bop Cassettes).

\section{Chapter 1}

\section{Counter-cultures: the cultural politics of pop}

1 J. Baudrillard: 'Hunting Nazis' in New Statesman, February 19, 1988.

2 See T. Young: 'The Fall of the House of Style' in New Society, August 2, 1985, and 'The Fashion Victims' in New Society, March 14, 1986.

3 T. Young: 'The Shock of the Old' in New Society, February 14, 1985, p. 246.

4 A. Martin and G. Hayes: 'The Eighties (A Fragment)' in E. Grosz et al (eds): Futur fall: Excursions into Post-Modernity (Power Institute of Fine Art, Sydney, 1986), p. 164.

5 Ibid., p. 161.

6 S. Frith: Sound Effects (Constable, London, 1983), p. 51.

7 Ibid., p. 52.

8 C. MacCabe: 'Broken English' in C. MacCabe (ed): Futures for English (Manchester University Press, Manchester, 1988), p. 9.

9 A. Goodwin: 'Music Video in the (Post)Modern World' in Screen, Vol 28 No 3, 1987, especially pp. 48-52.

10 See for different emphasis within this dichotomy, S. Rijven et al: Rock for Ethiopia (IASPM Working Paper 7, 1985), D. Hebdige: Hiding in the 


\section{Notes, references and select discography}

Light: On Images and Things (Routledge/Comedia, London, 1988), Ch. 9, and S. Hall: The Hard Road to Renewal (Verso, London, 1988), Ch. 17.

11 See, for a critical summary, M. Cousins and A. Hussain: Michel Foucault (Macmillan, London, 1984), Ch. 9.

12 See P. Hirst: After Thatcher (Collins, London, 1989).

13 S. Frith and H. Horne: Art into Pop (Methuen, London, 1987), p. 9.

14 S. Frith: Musicfor Pleasure (Polity Press, Oxford, 1988), Introduction, p. 1.

15 See F. Jameson: 'Postmodernism, or the Cultural Logic of Late Capitalism' in New Left Review, 146, 1984, 'The Politics of Theory' in New German Critique, 33, 1984, and 'Marxism and Postmodernism' in New Left Review, 176, 1989.

16 P. Wollen: 'Ways of Thinking about Music Video (and Postmodernism)' in C. MacCabe (ed): Future for English (Manchester University Press, Manchester, 1988).

17 Elton John - eventually - received a settlement of $£ 1$ million from the Sun newspaper during a high court case in which the singer sued the tabloid for falsely alleging his involvement in a 'rent-boy' racket.

18 CBS Songs Ltd and others $v$ Amstrad Consumer Electronic Plc and another, the Times, May 13, 1988, p. 21.

19 J. Baudrillard: Forget Foucault (Semiotext(e), New York, 1987), pp. 67-69.

20 See S. Redhead: Sing When You're Winning: The Last Football Book (Pluto Press, London, 1987); for those who didn't get the (elaborate) joke, the book's title and format were modelled on a parody of a particular sort of (punk) pop culture mode - essentially that espoused by Julie Burchill - especially evident in a book published by Pluto Press in the late 1970s, co-authored with Tony Parsons, called 'The Boy Looked at Johnny': The Obituary of Rock and Roll.

21 C. Gillett: The Sound of the City (Souvenir Press, London, 1983), p. 255.

22 S. Frith: 'Punk is Dead, Long Live Punk' in the Observer, March 16, 1986.

23 The term 'post-political' has distinct meaning within the body of work engendered by Jean Baudrillard - see S. Lotringer and C. Marazzi: 'The Return of Politics' in Italy: Autonomia: Post-Political Politics, Semiotext(e), No 9, 1980. Baudrillard's notion of the 'end of has been referred to elsewhere in this Chapter, but specifically in the context of the 'end of politics' his analysis seems to me to be 'fatally'(!) flawed. The notion of 'post-political' pop developed in this book should be seen as an attempt to find a more positive role for this concept. 


\section{The end-of-the-century party}

Various Artists: Bugs On The Wire (Leghorn) was the first compilation of Sunday afternoon favourites from Steve Barker's On The Wire programme; Bruce Springsteen: Born in the USA (CBS); John Cougar Mellencamp: The Lonesome Jubilee (Mercury); The Long Ryders: 'Looking For Lewis and Clark' EP (Island); Guadalcanal Diary: Jamboree (Elektra); Green On Red: Gas Food Lodging (Zippo); Jason and the Scorchers: Fervor (EMI America); The Smiths: The Queen is Dead (Rough Trade); REM: Murmur and Reckoning (IRS); George Michael: 'Faith' (Epic) stands as an example of one lineage of New Pop clashing with the so-called New Authenticity; Human League: 'Don't You Want Me' (Virgin); Scritti Politti: Cupid and Psyche, '85 (Virgin); Easterhouse: Contenders (Rough Trade); Housemartins: London 0 Hull 4 (Go! Discs); Beastie Boys; Licensed to Ill (Def Jam); Prince: Sign O The Times and Lovesexy (Paisley Park) and also the Black Album semi-illicitly bootlegged after Prince had fallen out with WEA; Michael Jackson: Bad (Epic); The Judds: Give a Little Love (RCA); Dwight Yoakam: Guitars, Cadillacs etc etc and Hillbilly Deluxe (Reprise); Nanci Griffith: The Last of the True Believers (Rounder), and Little Love Affairs (MCA); Lyle Lovett: Pontiac and And His Big Band (MCA); Randy Travis: Always and Forever (WEA); Steve Earle: Guitar Town (MCA); Pogues: Rum, Sodomy and The Lash (Stiff), and If I Should Fall from Grace with God (Pogue Mahone); That Petrol Emotion: Babble (Polydor); a good introduction to Cooking Vinyl's roster is found on Various Artists: Hot Cookies; also Cowboy Junkies: The Trinity Sessions (Cooking Vinyl); The Christians: The Christians (Island); The Go Betweens: Tallulah (Beggars Banquet); Simple Minds: Street Fighting Years (Virgin); Tracy Chapman: Tracy Chapman (Elektra); Enya: Watermark (WEA); Tanita Tikaram: Ancient Heart (WEA); Madonna: Like a Prayer (Sire); Sonic Youth: Bad Moon Rising (Blast First); Big Dipper: Boo Boo (Homestead); Dead Kennedys: Give me Convenience or Give me Death (Alternative Tentacles); Big Black: Songs about Fucking (Blast First); Nick Cave and the Bad Seeds: Kicking against the Pricks 


\section{Notes, references and select discography}

(Mute); We Free Kings: Hell on Earth and Rosy Cross (DDT); Gone To Earth: Folk in Hell and Vegetarian Bullfighter (Probe Plus); Camper Van Beethoven: Camper Van Beethoven (Rough Trade); Pet Shop Boys: Introspective (Parlophone); The Costello Show: King of America (F-Beat); Mark Stewart and the Maffia: As the Veneer of Democracy Starts to Fade and Mark Stewart (Mute); The Mekons: New York (Red Rhino, cassette); King of The Slums: Barbarous English Fayre (Play Hard); The Fall: The Wonderful and Frightening World Of and The Frenz Experiment (Beggars Banquet); Einstürzende Neubauten: Halber Mensch and Five on the Open-ended Richter Scale (Some Bizarre); Eric Clapton: Money and Cigarettes (WEA).

\section{Chapter 2}

\section{It all comes round again? Post-Subcultural Pop}

1 For instance, in Nigel Fountain and Peter Everett's documentary programme for BBC Radio 4, 'The Stylographers', which was first transmitted on September 29, 1988.

2 P. Morley: Ask: The Chatter of Pop (Faber and Faber, London, 1986), p. 128.

3 See I. Taylor and D. Wall: 'Beyond the Skinheads' in G. Mungham and G. Pearson (eds): Working Class Youth Culture (Routledge and Kegan Paul, London, 1976).

4 From H. Chappell: 'Vault Face' in the Guardian, April 21, 1987.

5 See, generally, for a useful account of the Manchester design network around Factory and Manchester Polytechnic, Tim Chambers' MA thesis, 'Leaving The Capitol: Manchester Pop Aesthetic. Graphic and Ideology, 1976-1988', Manchester Polytechnic Library.

6 L. Taylor: 'The Skin-Deep Revolution' in the Times, July 31, 1984.

7 J. Street: 'Red Wedge: Another Strange Story of Pop's Politics' in Critical Quarterly, Vol 30 No 3, 1988.

8 S. Redhead and E. McLaughlin: 'Soccer's Style Wars' in New Society, August 16, 1985.

9 See, for one such view, 'The Day the Music Died', in New Statesman and Society, February 10, 1989.

10 Quotations taken from interviews conducted with the author. 


\section{The end-of-the-century party}

11 S. Frith: 'Introduction' to C. McGregor: Pop Goes the Culture (Pluto Press, London, 1984), p. 5.

12 S. Reynolds: 'Fanzines: The Lost Moment' in Monitor, 1.

13 P. Cohen: 'Sore Thumb - Knuckle Sandwich Revisited' in Youth in Society, August 1980. See also, for Phil Cohen's mid-198os view, 'Towards Youthopia' in Marxism Today, October 1985.

14 G. Clarke: 'Defending Ski-Jumpers: A Critique of Theories of Youth Subcultures', Centre for Contemporary Cultural Studies, Stencilled Paper, University of Birmingham, June 1982.

15 P. Willis: Profane Culture (Routledge and Kegan Paul, London, 1978). Compare, however, Willis' work on youth for Wolverhampton Council in the 1980s, The Youth Review (Gower, Aldershot, 1988) and also 'Youth Unemployment: Ways of Living' in New Society, April 5, 1984.

16 M. Hustwitt: 'Rocker Boy Blues' in Screen, Vol 25, No 3, 1984. See also L. Cooke: 'Popular Culture and Rock Music' in Screen, Vol 24, No 3, 1983.

17 See M. Perniola: 'Time and Time Again' in Artforum, April 1983.

18 All quotations are from J. McDonald: 'Submission' in A. Frankovits (ed): Seduced and Abandoned: The Baudrillard Scene (Glebe, Stonemoss, 1984), pp. 24-25.

19 See on the design and musical aspects of rap and hip-hop, Joern Kroeger's undergraduate graphic design thesis, 'An Illustration and Discussion of the Rise in Popularity of Rap Music', Manchester Polytechnic Library, 1988.

20 P. Virilio (with S. Lotringer): Pure War (Semiotext(e), New York, 1983), p. 28.

21 Ibid., p. 26.

22 Ibid., p. 87.

23 M. Morris: 'At Henry Parkes Motel' in Cultural Studies, Vol 2, No 1, 1988, p. 3.

24 J. Berland: 'Placing Television' in New Formations, 4, 1988, p. 145.

25 Ibid., p. 146. See also J. Berland: 'Locating Listening' in Cultural Studies, Vol 2, No 3, 1988.

Fields of the Nephilim: Dawn Razor (Situation Two); The Mission: Children (Mercury); New Order: Low-Life, Brotherhood, Substance, and Technique (Factory); The Smiths: Strangeways Here we Come (Rough Trade); Half Man, Half Biscuit: Back in the DHSS and Back in the DHSS Again (Probe Plus); I, Ludicrous: 'Quite 


\section{Notes, references and select discography}

Extraordinary' and Its Like Everything Else (Kaleidoscope); Frank Sidebottom: 5:9:88 (In Tape); Latin Quarter: Modern Times (A\&M); A Certain Ratio: Force (Factory); Happy Mondays: Squirrel and GMan ..., and Bummed (Factory); Schoolly-D: Schoolly-D (Flame) is a good example of the macho 'braggard' hip-hop school; Cookie Crew: 'Females' (Serious) and Salt'n'Pepa: 'Push It' (Champion) are instances of female rap crews' response; also, for the development of rap and hip-hop: Spoonie Gee: 'The Godfather/Sure Delight' (Tuff City), Eric B and Rakim: 'I Know You Got Soul' (Cooltempo) and 'Paid in Full (Cold Cut Re-Mix)' (4th and Broadway), Public Enemy: 'Public Enemy No 1' (Def Jam); Mantronix: Music Madness (10); MC Buzz B: 'Slap Head' (Play Hard); also good hip-hop collections can be found on: Hip-hop, 20 (StreetSounds), Various Artists: The Word is Rap (Jive) including the Skinny Boys; Various Artists: The Best of West Coast Hip hop (StreetSounds), featuring Ice T amongst others; Various Artists: Beat the Freaks (Celluloid) which includes the classic original rappers The Last Poets and even New York avant-'rockers' the Golden Palominos; and Various Artists: The B-Boy/Boogie Down Sampler Vol 2 (Westside), including KRS-One and Cold Crush Brothers on a celebration of two of New York's best known rap labels; for house compilations House Sound of Chicago Vol 1, 2 and 3 (ffrr), the latter being one of the earliest to focus on 'Acid'; for the best instances of Acid House, Various Artists: Acido Amigo (Westside) featuring Tyree, Jack Rabbit (aka Adonis) and Humanoid who had a chart single 'Stakker Humanoid'; DJ Fast Eddie's 'hip-house' mixture is best heard on Jack to the Sound (DJ International); T-Coy: 'Carino' (De/Construction) is house straight from the Haçienda's mouth.

\section{Chapter 3}

\section{Soundtracks from the global hypermarket: post-pop politics}

1 M. Omi: 'A Positive Noise: The Charity Rock Phenomenon' in Socialist Review, 86, 1986, p. 111. 


\section{The end-of-the-century party}

2 S. Connor: 'The Flag on the Road' in New Formations, 3, 1987 and S. Connor: Postmodernist Culture (Blackwell, Oxford, 1989).

3 M. Kohn: 'Hip Little Englanders' in Marxism Today, November 1983.

4 M. Harron: 'No One's Fault' in New Statesman, November 19, 1982.

5 Martin and Hayes, 'The Eighties (A Fragment)', p. 164.

6 See S. Frith: 'Frankie Says Buy Me' in Onetwothreefour, 2, 1985.

7 J. Baudrillard: The Evil Demon of Images (Power Institute of Fine Art, Sydney, 1987), p. 16.

8 For a critical study of this term as developed by theorists such as Antonio Gramsci, see D. Forgacs: 'National-Popular: the Genealogy of a Concept' in T. Bennett et al (eds): Formations: Of Nation and People (Routledge and Kegan Paul, London, 1984).

9 I.A. Anderson: 'Editorial' in Folk Roots, June 1986.

10 I.A. Anderson: 'A World Music Meeting' in Folk Roots, July 1986.

11 R. Denselow: 'Folk-Rock in Britain' in D. Laing et al: The Electric Muse (Eyre Methuen, London, 1975).

12 Interview on 'Saturday Live' on BBC Radio 1, April 27, 1985.

13 S. Frith: 'Rock Goes back to the Real Stuff' in the Observer, May 6, 1985.

14 I.A. Anderson: 'Editorial' in Folk Roots, August 1986.

15 Interview with the author.

16 Interview in City Life, April 5-26, 1984.

17 Interview with the author.

18 The programme on Ry Cooder was broadcast on February 27, 1983, and presented by the late Alexis Korner. See also the book of the series, edited by John Tobler and Stuart Grundy, The Guitar Greats (BBC Publications, London, 1983).

19 M. Kohn: Narcomania (Faber and Faber, London, 1987), p. 168.

20 F. Jameson: 'Postmodernism and Consumer Society' in H. Foster (ed): Postmodern Culture (Pluto Press, London, 1985).

21 Interview with the author.

22 See J. Walker: Cross-Overs (Comedia/Methuen, London, 1987).

23 Frith, Sound Effects, p. 29.

24 D. Hebdige: Subculture: The Meaning of Style (Methuen, London, 1979).

25 D. Hebdige: Cut ' $n$ ' Mix (Comedia/Methuen, 1987), p. 158.

26 R. Davis: 'Anti-Pop but not Iggy Pop' in Left Curve, 12, 1987-8.

27 J. Murphy: 'Interview with Fredric Jameson' in Left Curve, 12, 1987-8, p. 11.

28 Ibid., p. 11. 


\section{Notes, references and select discography}

29 Editorial, Left Curve, 12, 1987-8.

30 L. Hutcheon: A Poetics of Postmodernism (Routledge, London, 1988), p. 60.

31 Ibid., p. 61.

32 Ibid., p. 67.

33 Quotations taken from interviews with the author.

Michael Chapman: Heartbeat (Coda); Incantation: Panpipes of the Andes (Coda); Claire Hamill: Love in the Afternoon (Coda); Various Artists: First Impressions (Coda); Robert Cray Band: Bad Influence and False Accusations (Demon); Anita Baker: The Songstress, Rapture and Giving you the Best that I Got (Elektra); Luther Vandross: Give me the Reason (Epic); Melis'a Morgan: Do Me Baby (Capitol); Bruce Springsteen: Live 1975-1985 (5 album boxed set, CBS); Frankie Goes to Hollywood: Welcome to the Pleasure Dome (ZTT); Ketama: Ketama (Hannibal); Les Mystere Des Voix Bulgares: Vol 2 (4AD); Balkana: The Music of Bulgaria (Hannibal); Marta Sebestyen and Muzsikas: Marta Sebestyen (Hannibal); 3 Mustaphas 3: Bam! Mustaphas Play Stereo (GlobeStyle); Bhundu Boys: True Jit (WEA); Ali Farka Toure: Ali Farka Toure (World Circuit); Stella Chiweshe: Ambuya? (GlobeStyle); Toumani Diabate: Kaira (Hannibal); Jali Musa Jawara: Soubindoor (World Circuit); Salif Keita: Soro (Sterns); The Real Sounds: Wende Zako (Cooking Vinyl); Various Artists: Thunder Before the Dawn: The Indestructible Beat of Soweto, Vol 2 (Earthworks/Virgin); The Oyster Band: Wide Blue Yonder (Cooking Vinyl); Band of Holy Joy: 'Rosemary Smith' (Flim Flam); for a Billy Bragg 'soundalike' who encountered the same problems see Rodney Allen: Happysad (Subway); Sweet Honey in The Rock: The Other Side (Making Waves); The Sugarcubes: 'Birthday', 'Deus' and 'Cold Sweat' (One Little Indian); Throwing Muses: Throwing Muses, 'Chains Changed' EP, The Fat Skier and House Tornado (4AD); Golden Palominos: Visions of Excess (Celluloid); 10,000 Maniacs: Human Conflict No 5 and Blind Man's Zoo (Elektra); Rory McLeod: Angry Love (Forward); The Proclaimers: This is the Story (Chrysalis); Richard Thompson: Amnesia 


\section{The end-of-the-century party}

(Capitol); The Men They Couldn't Hang: 'Gold Rush/The Ghosts of Cable Street' (MCA) and Night of a Thousand Candles (Imp); Dick Gaughan: True and Bold (STUC); Christy Moore: Unfinished Revolution (WEA); Michelle Shocked: Short Sharp Shocked (Cooking Vinyl); Phranc: Folksinger (Stiff); Loudon Wainwright III: More Love Songs (Demon); Jackson Browne: Lives in the Balance (Geffen); Joni Mitchell: Dog Eat Dog (Geffen); Andy White: Rave On (Decca); Felt: Forever Breathes the Lonely Word (Creation); Peter Case: The Man with the Blue Postmodern Fragmented Neo-Traditionalist Guitar (Geffen); Martin Stephenson and the Daintees: Boat to Bolivia (Kitchenware); Leonard Cohen: I'm Your Man (CBS); Prefab Sprout: Swoon, Steve McQueen, From Longley Park to Memphis and Protest Songs (Kitchenware); Terry Allen: Bloodlines (Making Waves); Rhythm Sisters: Road to Roundhay Pier (Red Rhino); Paul Simon: Graceland (WEA); Ted Hawkins: On the Boardwalk (UnAmerican Activities); S.E. Rogie: Palm Wine Guitar Music (Cooking Vinyl); Clive Gregson: Strange Persuasions (Demon); Ry Cooder: 'Get Rhythm' (WEA); Los Lobos: How Will The Wolf Survive? (Slash/London); Jesus and Mary Chain: 'April Skies' (Blanco Y Negro); The Bodines: 'Therese' (Creation); The Pastels: Up for a Bit With (Glass); Primal Scream: Sonic Flower Groove (Elevation); That Petrol Emotion: Manic Pop Thrill (Polydor); Any Trouble: Wrong End of the Race (EMI America); The Soup Dragons: 'Whole Wide World' (Subway); Razorcuts: 'Sorry To Embarass You' (Subway); Shop Assistants: Shop Assistants (Blue Guitar); Ofra Haza: 'Im Nin' Alu', and Yemenite Songs (GlobeStyle); Van Morrison and The Chieftains: Irish Heartbeat (Mercury); Relativity: Relativity (Green Linnet); Heb Gariad: 'Caneuon O' R De' (Anhrefn); also Keltia-Rok (Sain), which was the first record to bring together rock music in the six Celtic languages (Welsh, Cornish, Breton, Irish, Manx, Scottish Gaelic); The Chills: Brave Words (Flying Nun); for reverential postpunk Johnny Cash, Various Artists: Til Things Get Brighter (Red Rhino). 


\section{Notes, references and select discography}

\section{Chapter 4}

\section{One nation under a hoof: whatever happened to the new bohemia?}

1 Hebdige, Subculture: The Meaning of Style, p. 148.

2 J. Savage: 'Dead Souls' in New Statesman, February 6, 1987.

3 Quoted in Melody Maker, March 28, 1987.

4 See S. Hall: 'The Hippies: An American Moment' (Stencilled paper, Centre for Contemporary Cultural Studies, University of Birmingham, 1968).

5 Savage, 'Dead Souls'. See also P. Vincent-Jones: 'Private Property and Public Order: The "Hippy Convoy" and Criminal Trespass' in Journal of Law and Society, Vol 13 No 3, 1986 and M. Clarke: The Politics of Pop Festivals (Junction Books, London, 1982).

6 R. Hewison: Too Much (Methuen, London, 1986), p. xi.

7 R. Duncan: The Noise: Notes from a Rock'n'Roll Era (Ticknor and Fields, New York, 1984), p. 11.

8 Quoted in R. Woliver: Bringing It All Back Home (Pantheon, New York, 1986), p. 31.

9 P. York: Style Wars (Sidgwick and Jackson, London, 1980), p. 182. The Chapter was originally published in Harpers and Queen, January 1978.

10 G. Marcus: 'Speaker to Speaker' column Artforum, March 1987.

11 See B. Dessau: 'Shamble City' in City Limits, April 17-24, 1986.

12 S. Reynolds: 'MOR or Less' in New Statesman, December 19/26, 1986. See also Reynolds' other excellent pieces on shambling - 'Younger than Yesterday' in Melody Maker, June 28, 1986, 'Ladybirds and Start RiteKids' in Melody Maker, September 27, 1986, and his article on Talulah Gosh in Melody Maker, November 13, 1986.

13 Frith, 'Punk is Dead, Long Live Punk'.

$14 i-D, 46,1987$.

15 S. Frith: 'The Punk Bohemians' in New Society, March 9, 1978, my emphasis.

16 M. Middles: The Smiths (Omnibus, London, 1985), p. 38.

17 Quotation from interviews with Dave Haslam by the author. One of the earliest and most revealing interviews with Morrissey was conducted by Dave Haslam and appeared in Debris issue 2 in 1984. Haslam argued in the preface that Morrissey's 'heroines of the 6o's (Sandie Shaw, Dusty Springfield) might seem to be unashamedly innocent and 


\section{The end-of-the-century party}

honestly charming in what they do, but that whole image was as much a marketing ploy as any in use in today's music business.'

18 P. Willis: 'Young, Gifted and Forgotten' in New Socialist, Summer 1988.

19 J. Attali: Noise: The Political Economy of Music (Manchester University Press, Manchester, 1985).

MC Buzz B: 'How Sleep The Brave' (Play Hard); Benny Profane: Trapdoor Swing (Play Hard); The Bodines: 'Decide' (Play Hard); The Train Set: 'She's Gone', and 'Hold On' (Play Hard); much hardcore 'punk' and 'rock', and thrash, speed and even death 'metal', takes on the two traditions, punk and hippy, in its three chord hi-velocity thrash and its long-hair styles - for British examples, Doom: War Crimes: Inhuman Beings (Peaceville); Toranga: Bastard Ballads (Peaceville); Deviated Instinct: Rock'n'Roll Conformity (Peaceville); Gold, Frankincense and Disk Drive: Where do we Draw the Line (Peaceville); Gaye Bikers on Acid: Drill Your Own Hole (in Tape), and Various Artists: A Vile Peace (Peaceville); Hüsker Dü: Candy Apple Grey (SST) and Warehouse: Songs and Stories (WEA) are still probably the outstanding examples from either side of the midAtlantic; for North American punk, 'hardcore' and beyond in the wake of Hüsker Dü's first album Land Speed Record (New Alliance/ SST), play also: Black Flag: Damaged (SST) featuring the vocals of Henry Rollins; Blast: Its in My Blood (SST); The Jesus Lizard: Pure (Touch and Go); The Descendents: Two Things at Once (SST); The Didjits: Hey Judester (Touch and Go); Die Kreuzen: 'Gone Away', and Century Days (Touch and Go); Laughing Hyenas: Merry Go Round (Touch and Go); Pailhead: Trait (Wax Trax); Flour: Flour (Touch and Go); Fire Party: Fire Party and New Orleans Opera (Dischord); Killdozer: 'Lupus/Nasty' (Touch and Go); SNFU: Better Than a Stick in the Eye (Cargo); and Various Artists: The New Sound Of Rock (Celluloid); though this is mostly a 'white' musical form there are exceptions like the all black band Bad Brains: I Against I (SST); though this is usually a genre best exemplified by 


\section{Notes, references and select discography}

American bands, play Silverfish: 'Silverfish' EP (Wiiija) and Bastard Kestrel: Oh Stupid Mushroom (Wiiija); The Cult: Electric, and Love (Beggars Banquet) relied on less punk, some Goth and a more traditional combination of 1960 s and 1970s rock styles; for up to the minute accounts of bands and labels - like Seattle's Sub Pop - see the US magazine Maximium rock and roll; from another perspective altogether, Black Sun Ensemble: Black Sun Ensemble (Reckless) revive a style and sound from the late 1960s wholesale; for an example of the 'new jazz' see Courtney Pine: Destiny's Song and the Image of Pursuance (Antilles/Island); for one version of British 'indie' pop of the mid-late 1980s: The Woodentops: Giant (Rough Trade); The Rosehips: 'Room in Your Heart', and 'I Shouldn't Have To Say' (Subway); Talulah Gosh: 'Steaming Train' (53rd and 3rd); The Primitives: 'Stop Killing Me' (Lazy); The Flatmates: 'Shimmer', 'You're Gonna Cry' and 'Happy All the Time' (Subway); and The Chesterfields: Westward Ho and Kettle (Subway); for Morrissey post-Smiths, but with Durutti Column's Vini Reilly: Viva Hate (HMV); for sub/post Smiths shambling guitar bands: The Wedding Present: 'Why Are You Being So Reasonable Now?' (Reception); The Railway Children: Reunion Wilderness (Factory); Bradford: 'Skin Storm' (Village); Various Artists: The Edge of the Road (Medium Cool) featuring the Waltones and Corn Dollies; and The Waltones: 'Spell It Out' (Medium Cool); for less irony and more straightforward reworking of pop and rock tradition: Inspiral Carpets: The Peel Sessions (Strange Fruit) and The Stone Roses: The Stone Roses (Silvertone); for 'left-field' bands in the mould of a mixture of Big Flame and Captain Beefheart see: Dub Sex: Push (Ugly Man) and 'The Underneath' (Cut Deep); and Death By Milkfloat: 'The Absolute Non-End' EP (Ediesta); for the sound of 'white' American new bohemia, Pere Ubu: The Tenement Year (Fontana); The Pixies: Surfer Rosa (4AD); Swans: 'Time is Money (Bastard)' (K422) and This Burning World (MCA). 


\section{The end-of-the-century party}

\section{Chapter 5}

\section{Don't go back to rockville: Post-Political Pop}

1 See I. Chambers: 'Maps For the Metropolis: A Possible Guide to the Present' in Cultural Studies, Vol 1, No 1, 1987, and 'Contamination, Coincidence and Collusion: Pop Music, Urban Culture and the Avant-Garde' in L. Grossberg and C. Nelson (eds): Marxism and the Interpretation of Culture (University of Illinois Press, Urbana, 1988); and D. Hebdige: 'The Impossible Object: Towards a Sociology of the Sublime' in New Formations, 1, 1987.

2 McDonald, 'Submission', p. 23.

3 R. Harley: 'Hiding in the Light: Extended Club Mix with Dick Hebdige' in Art and Text, 26, 1987, p. 70.

4 See A. Chester: 'For A Rock Aesthetic' in New Left Review, 59, 1970, R. Merton: 'Comment' in New Left Review, 1970, A. Chester: 'Second Thoughts on a Rock Aesthetic' in New Left Review, 62, 1970, and S. Frith: 'Towards an Aesthetic of Popular Music' in R. Leppert and S. McClary (eds): Music and Society (Cambridge University Press, Cambridge, 1987).

5 A. Durant: Conditions of Music (Macmillan, London, 1984), Ch. 6.

6 S. Frith: 'Art Theory and Pop Practice' in L. Grossberg and C. Nelson (eds), Marxism and the Interpretation of Culture.

7 J. Burchill: 'Adorno and Rice' in New Society, December 18, 1987.

8 S. Frith: 'Why Do Songs Have Words?' in A. L. White (ed): Lost in Music, Sociological review monograph, University of Keele, 34 (Routledge, London, 1987).

9 Interviews with the author.

10 See J. Dawe: 'Relationship Between Experimental "Rock" Music and Experimental “Art” Music', undergraduate Fine Art thesis, Humberside College of Higher Education, 1988.

11 Interviews with the author.

12 Raymond Williams: Towards 2000 (Chatto \& Windus, 1983), p. 84.

Sonic Youth: Daydream Nation (Blast First); Various Artists: Funky Alternatives(Concrete); African Head Charge: Off the Beaten Track and Environmental Studies (On-U Sound); Singers and Players: Staggering Heights and Vacuum Pumping (On-U Sound); Gary Clail's Tackhead 
Sound System: Tackhead Tape Time (Nettwerk); Tackhead: Friendly as a Hand Grenade (World Records); Lee 'Scratch' Perry and Dub Syndicate: Time Boom X de Devil Dead (EMI); Dub Organiser: 'I've Got A Weapon' (Play Hard); What?noise: 'Vein' EP (Cut Deep); Thule: 'Le Jamais Contente' EP (Wiiija); The Shamen: 'Jesus Loves Amerika' (Ediesta); Gang of Four: The Peel Sessions (Strange Fruit); Run DMC: Tougher Than Leather (Profile); Public Enemy: It Takes a Nation of Millions to Hold us Back (Def Jam); Cold Cut: 'Doctorin The House' (Ahead of Our Time); Eric B and Rakim: Follow The Leader (MCA); S-Express: 'Theme From S-Express' (Rhythm King); Bomb The Bass: 'Enter The Dragon' (Rhythm King); Yazz: 'Fine Time' (Big Life); for much litigated sampling, Justified Ancients of $\mathrm{Mu} \mathrm{Mu}$ : Who Killed the JAMS? (KLF); for all-women reggae, Akabu: Akabu (Viva).

\section{The absolute non-end}

1 For a stimulating debate on the reformulation of the authentic/ inauthentic dichotomy see L. Grossberg et al: It's a Sin (Power Publications, Sydney, 1988). 